\title{
LEARNERS' MOTIVATION AND ATTITUDE IN NON-FORMAL EFL EDUCATION: A CASE STUDY OF ENGLISH CLASS AT BABE BERBAGI COMMUNITY IN D.I.YOGYAKARTA, INDONESIA
}

\author{
Alvan Bastoni Nuradila \\ alvanbastonin@gmail.com \\ Graduate Student of Linguistics \\ Universitas Gadjah Mada
}

\begin{abstract}
Learners' motivation and attitude are some of those key elements influencing the progress of language learning. It is widely believed that the better the learners' motivation and attitude, the better the result of the learning process is. This study is aimed to see the motivation and attitude of English for foreign language (EFL) learners in non-formal setting. The participants of this study is the English learners of BaBe Berbagi community in D.I. Yogyakarta, Indonesia. Non-formal education in this research would not benefit the learners with any legal letters, so this study revealed the underlying factors that motivate them to join the class. The data analysis involving a group separation based on the age of the participant to give some insights on how the motivation and attitude change by the time the learners grow up. Two groups of participants were made and some declines of motivational development occurred on some factors such as interest in foreign language, caregivers' encouragement, intrinsic motivation, and anxiety. This study also identified that the older group developed more instrumental motivation than the younger group and showed less anxiety about the target language. The result of the research can affect the sustainability, the learning process, and the goal of the English learning program in the community.
\end{abstract}

Keywords: motivation, attitude, language learning, EFL, BaBe Berbagi Community, non-formal education.

\section{INTRODUCTION}

The learners' motivation and attitude towards second language (L2) learning comprises some the learners' sociocultural background. It also shows the psychological consideration in the learners' mind about the target language (L2). Those sociocultural and psychological aspects about the learner's perception towards the language and the language learning program become a pivotal component in creating a good learning process. Those perceptions become the learners' motivation attitude that can either hinder or boost up their second language acquisition (SLA) process. English is treated as a foreign language in Indonesia. English for foreign language (EFL) is a common English learning context used in Indonesian formal education. However a distinction may exist in vocational high schools in which the students need to learn English through English for specific purpose (ESP) materials.

To this recent date in Indonesia, English is not generally taught at elementary schools. Some elementary schools may have English as their compulsory subject, while some others may not 
due to a difference in implementing the curriculum allowing the schools to add its specific subject in which English may become one of the school-added compulsory subject.

The affinity to learn English does not only existed in the formal educational context. In nonformal educational context, there are some local communities letting its members to learn English. Those communities accommodate different purpose of learning English some of them may concentrate their activities on the ESP program while some others may, in line with the government, use EFL program. That difference comes as the result of the variety of learners' target needs. Some of them may have adults while some others may get children as the English learners.

This study is trying to reveal the motivation and attitude of the children who join a non-formal English language learning program held by BaBe Berbagi, a D.I.Yogyakarta, a province in Indonesia, based community which teach EFL to the children. The children are volunteering to join the program outside of school hours.

This study may shed us some light in understanding the developmental factors of motivation and attitude so that the children in the BaBe Berbagi community's English class joined the program despite the fact that the English learning program is a non-formal education where the learners will not be given with any reward or acknowledgement in the form of a legal letter.

\section{LITERATURE REVIEW}

Motivation and attitude has a great impact on the second language acquisition (SLA) (Gardner, 2006). In Gardner \& MacIntyre's (1993) socioeducational model of SLA, learners' motivation and attitude become some pivotal elements in informal language context affecting linguistics and non-linguistics outcomes of the learners. Motivation is important to create an effective instruction (Winne and Marx, 1989). For many years, motivation has been widely studied in the field of psychology and education (Dörnyei, 2001a). That may arise from the teachers' awareness that the students' motivation is a vital element to create a successful educational environment (Dörnyei, 2001b).

According to Gardner (1985), motivation in learning L2 is "referring to the extent to which the individual works or strives to learn the language because of a desire to do so and the satisfaction experienced in this activity" (p. 10). A notable categorization of motivation in psychological motivational theory is intrinsic and extrinsic motivation (Dörnyei, 2001a). Intrinsic motivation is "motivation to engage in an activity for its own sake" while extrinsic motivation is "motivation to engage in an activity as a means to and end" (Pintrich \& Schunk, 2002). Noels, Pelletier, Clément, and Vallerand (2000) has developed a systematic model to introduce the intrinsic and extrinsic motivation into SLA, however there is not any satisfactory number of research about those two kinds of motivation in the case of foreign language learning including in English for foreign language (EFL) (Carreira, 2006).

Besides, there are also two types of motivation suggested by Gardner and Lambert (1972) which are integrative motivation, and instrumental motivation. Integrative motivation deals with positive attitudes and feelings toward the target language, whereas instrumental motivation focuses its attention to potential practical use of the second language (L2) proficiency, to get a better job or higher salary for instance.

Oroujlou and Vahedi (2011) state that there is "direct relationship between the efficiency of the students in language classes, and motivation and attitude" (p. 998). Their study is focused on the role of the learners' motivation and attitude in language learning. They describe that motivation 
and attitude are essential in creating an effective learning program and also in developing the learners' proficiency. Their work is based on a research on various literatures about language learning and social psychology.

There are some studies trying to see the relation of the children's age with their motivation and attitude development. Nikolov (1999) shows that before the children reached 11 years old, there is not any instrumental motivation revealed in their learning process. The children's motivation is risen because of the classroom and teacher related motivation. So the classroom environment plays the most important role in affecting the children's motivation and attitude. It is in the age of 11 or 12 years old that the children's instrumental motivation is appeared.

A completely different result is founded by Carreira (2006) in which there is a decrease the motivation and attitude developmental factors of the EFL learners. The decline occurs in all of the factors which are interest in foreign countries, intrinsic motivation, caregivers' encouragement, instrumental motivation, and anxiety. The decline ensues as the participants, Japanese elementary school students, reached 11 years old. The study assumes that the decrease had something to do with some external factors such as education, teachers, parents, peers, and the classroom.

\section{METHOD}

This research is a quantitative study with descriptive and inferential design. The data were gathered from English learners in the English learning program held by BaBe Berbagi community in D.I.Yogyakarta, Indonesia. The participants were elementary school children coming from the neighborhood ranging from the first to the fifth grade of elementary schools. The participants were 8-11 years old, and categorized into two groups. The first group consisted of those who are 8-10 years old and the second group consisted of those who are 11 years old. The number of the participants in each group is 5. The English learning program in BaBe Berbagi community is an EFL program in nature, applying general English (GE) materials.

The data were obtained in the middle of program's period through a questionnaire. Motivation and Attitudes toward Learning English Scale for Children (MALESC) was used to obtain the data. MALESC is a questionnaire designed by Carreira (2006) to assess the motivation and attitude of the children in learning English, especially in SLA context. The questionnaire consists of 19 items and categorized into five factors. MALESC is designed to know about the participants' "motivation to learn English, interest in foreign countries, caregivers' encouragement, and anxiety" (Carreira, 2006, p. 144).

Table 1. MALESC Factors Item

\begin{tabular}{|c|c|c|}
\hline Item & Question & Factor \\
\hline 2. & I would like to go to various foreign countries. & \multirow{5}{*}{$\begin{array}{c}\text { Factor 1: } \\
\text { Interests } \\
\text { in Foreign } \\
\text { Countries }\end{array}$} \\
\hline 4. & I would like to make a lot of foreign friends. & \\
\hline 12. & $\begin{array}{l}\text { I would like to try and talk to foreigners when my English } \\
\text { becomes proficient. }\end{array}$ & \\
\hline 15. & I would like to live abroad. & \\
\hline 17. & I would like to know more about foreig & \\
\hline 1. & English lessons are great fun. (I really enjoy learning $\mathrm{F}$ & \multirow{3}{*}{$\begin{array}{c}\text { Factor 2: } \\
\text { Intrinsic } \\
\text { Motivatio }\end{array}$} \\
\hline 3. & I always look forward to the day when we have English class. & \\
\hline 6. & I would like to try to use the English which I have learned. & \\
\hline
\end{tabular}




\begin{tabular}{|c|c|c|}
\hline 8. & I hope that we have more English lessons. & $\mathrm{n}$ \\
\hline 9. & $\begin{array}{l}\text { In my family, we all feel that it is very important to learn } \\
\text { English. }\end{array}$ & \multirow{3}{*}{$\begin{array}{c}\text { Factor 3: } \\
\text { Caregivers } \\
\text { Encourage } \\
\text { ment }\end{array}$} \\
\hline 13. & My parents hope that my English will be proficient. & \\
\hline 18. & My parents tell me to study English hard. & \\
\hline 7. & $\begin{array}{l}\text { I study English in order to make English easier for me in junior } \\
\text { high school. }\end{array}$ & \multirow{4}{*}{$\begin{array}{c}\text { Factor 4: } \\
\text { Instrument } \\
\text { al } \\
\text { Motivatio } \\
\text { n }\end{array}$} \\
\hline 11. & $\begin{array}{l}\text { I study English because I think English will be necessary for me } \\
\text { when I am an adult. }\end{array}$ & \\
\hline 14. & I am studying English for a future job. & \\
\hline 19. & $\begin{array}{l}\text { I am studying English in order to enter a high school or a } \\
\text { university. }\end{array}$ & \\
\hline 5. & $\begin{array}{l}\text { I get worried when I am doing worse than my classmates in } \\
\text { English class. }\end{array}$ & \multirow[t]{3}{*}{$\begin{array}{l}\text { Factor 5: } \\
\text { Anxiety }\end{array}$} \\
\hline 10. & I am somehow always anxious in the English class. & \\
\hline 16. & $\begin{array}{l}\text { I get nervous when I answer or give a presentation in English } \\
\text { class. }\end{array}$ & \\
\hline
\end{tabular}

Carreira (2006) states that the question items in the MALESC questionnaire can be classified into five factors which are Interest in foreign countries, intrinsic motivation, caregivers' encouragement, instrumental factors and anxiety. As its name suggests, MALESC questionnaire should include at least an element related with the learners' attitude. A problem might arise since the categorization of the question items in MALESC does not explicitly include any attitude element. However if we compare it with the Attitude and Motivation Test Battery (AMTB) designed by Gardner (1985) there are some items in the intrinsic motivation factors which can be used to assess the attitude of the learners such as item 1 and 8 . Thus it is assumed that the MALESC have included the attitude aspect inside the intrinsic motivation factor.

The collected data was analyzed to find the mean (M) as well as the standard deviation (SD) of each question item. Similar treatment is also applied to each factors of the question item. Those $\mathrm{M}$ and SD are transcribed into descriptive analysis to show the condition of the participants. The data analysis was then categorized into a general result showing the data analysis of all participants $(\mathrm{n}=10)$ and an age group result which divide the participants into two groups consisting under 11 years old participants $(n=5)$ and 11 years old participants $(n=5)$.

\section{FINDINGS AND DISCUSSION}

The general result of the study came from the data analysis of all participants $(n=10)$ without dividing them into certain group. Based on the obtained data, each item of the questionnaire was analyzed to find its $M$ and $S D$. Descriptive statistics for individual items of the data can be seen in table 2.

Table 2. Descriptive Statistics for Individual Items

\begin{tabular}{|c|c|c|}
\hline Item & $M$ & $S D$ \\
\hline Q1 & 3.5 & 0.53 \\
\hline Q2 & 3.3 & 0.67 \\
\hline Q3 & 3.4 & 0.52 \\
\hline Q4 & 2.7 & 0.67 \\
\hline Q5 & 2.7 & 1.25 \\
\hline Q6 & 3.6 & 0.52 \\
\hline
\end{tabular}




\begin{tabular}{|c|c|c|}
\hline Q7 & 3.7 & 0.48 \\
\hline Q8 & 3.4 & 0.52 \\
\hline Q9 & 3.4 & 0.52 \\
\hline Q10 & 2.2 & 1.03 \\
\hline Q11 & 3.6 & 0.52 \\
\hline Q12 & 3.2 & 0.63 \\
\hline Q13 & 3.5 & 0.53 \\
\hline Q14 & 3.2 & 0.92 \\
\hline Q15 & 2.3 & 0.95 \\
\hline Q16 & 1.7 & 0.95 \\
\hline Q17 & 3.4 & 0.70 \\
\hline Q18 & 3.5 & 0.53 \\
\hline Q19 & 3.6 & 0.52 \\
\hline
\end{tabular}

Note: strongly agree $=4$. agree $=3$. disagree $=2$. strongly disagree $=1$

The descriptive statistics for individual items, as can be seen in table 2, showed that the $M$ and $\mathrm{SD}$ of each item were quiet normal with only four item having $\mathrm{M}$ score below 3 points meaning that the participants were not really agree with the statement in question items. The SD of the question items are considered low with almost all of them falls below 1 point. There are only two items, number 5 and 10, which score above 1 point.

Table 3. Descriptive Statistics for Five Factors

\begin{tabular}{|l|l|c|c|c|c|}
\hline No. & \multicolumn{1}{|c|}{ Factor } & Min & Max & $M$ & $S D$ \\
\hline 1. & Factor 1: Interest in Foreign Countries & 5.00 & 20.00 & 14.9 & 2.38 \\
\hline 2. & Factor 2: Intrinsic Motivation & 4.00 & 16.00 & 13 & 1.73 \\
\hline 3. & Factor 3: Caregivers' Encouragement & 3.00 & 12.00 & 10.4 & 1.51 \\
\hline 4. & Factor 4: Instrumental Motivation & 4.00 & 16.00 & 14.1 & 1.91 \\
\hline 5. & Factor 5: Anxiety & 3.00 & 12.00 & 6.6 & 2.41 \\
\hline
\end{tabular}

The data analysis showed that all of the factors have a score above the half of its max score. Factors 1, 2, 3, and 4 are considered as positive factors indicating a positive motivation and attitude of the participants. However, there is a negative response showed by the score of anxiety of the participants in the learning program. Although the score gap between the half score of the anxiety factor, which is 6 , and its $M$ score is quite small (only 0.6 points) but it is significant enough to show that the participants feel anxious about their use of English in the learning program.

The small number of the participants made a slight difference in SD score, which means a noteworthy disperse of participants' answers. There were two factors having SD score more than 2 points. Those factors were about the interest in foreign countries and also the anxiety. It means that a small number of participants may think differently with the others in the case of their interest in foreign country in which they feel that they are less interested about foreign countries. The anxiety SD score also showed that some of the participants might not feel really anxious about their use of English in the learning program.

To see the correlation between the age and the motivation of learning second language, two groups of participants were created. The first group consisted of the participants who were under 11 years old $(n=5)$ while the second group consisted of the participants who were 11 years old $(n=5)$. The participants in the first group were ranging from 8-10 years old. 
Table 4. Descriptive Statistics for Five Factors of the Under 11 Years Old Participants $(\mathbf{n}=\mathbf{5})$

\begin{tabular}{|l|l|c|c|c|c|}
\hline \multirow{2}{*}{ No. } & \multicolumn{2}{|c|}{ Factor } & \multicolumn{2}{c|}{ Group 1 } & \multicolumn{2}{c|}{ Group 2 } \\
& & \multicolumn{2}{|c|}{ Under 11 years old } & \multicolumn{2}{c|}{11 years old } \\
\cline { 3 - 6 } & & $M$ & $S D$ & $M$ & $S D$ \\
\hline 1. & Factor 1: Interest in Foreign Countries & 15.4 & 3.29 & 14.4 & 1.14 \\
\hline 2. & Factor 2: Intrinsic Motivation & 14.4 & 1.81 & 13.4 & 1.67 \\
\hline 3. & Factor 3: Caregivers' Encouragement & 10.8 & 1.64 & 10 & 1.41 \\
\hline 4. & Factor 4: Instrumental Motivation & 13.4 & 1.95 & 14.8 & 1.79 \\
\hline 5. & Factor 5: Anxiety & 7.8 & 2.77 & 5.4 & 1.34 \\
\hline
\end{tabular}

The statistics of the first group in Table 4, consisting of the participants under 11 years old, showed that in overall they have positive motivation. It was depicted by their scores of factor 1 , 2, 3, and 4 which fell above the half point of the M. In regard to the learners' attitude in the learning program, they felt anxious about making a mistake in the learning program showed by the score of factor 5 which fell above the half point of its $\mathrm{M}$.

However, there was an interesting case with the SD score of the first group concerning with factor 1 and 5. While the SD scores on the others factor were relatively on the range of point 1 , the SD score of the factor 1 was above 3 points and the SD score of the factor 5 almost reached 3 points. It meant that there were some participants in the first group who were really interested in foreign country more than the other participants. It also meant that there were some participants who did not feel really anxious about making mistake in the class.

The statistics of the second group consisting of 11 years old participants, identified on Table 3, revealed that the 11 years old students had positive motivation towards the language learning program. It was depicted by their $\mathrm{M}$ score in factor 1, 2, 3, and 4 which fell above the half of its max score. It was also exposed that the participants had positive attitude about the learning program since they had low anxiety score in factor 5. Those participants did not feel anxious about making a mistake in the language learning program.

The result of this study revealed that there were some declines on motivational development of the non-formal EFL learners as the participants reached 11 years old. The declines are in line with the result of Carreira (2006). However the declines showed by the analysis of four factors. Those factors were interest in foreign countries, intrinsic motivation, caregivers' encouragement, and anxiety.

The data analysis of this study also showed a similarity with the study conducted by Nikolov (1999) that the instrumental motivation arise when the children gets 11 years old. This study exposed that there was an increase on motivational development in the case of instrumental motivation when the non-formal EFL learners.

It could be interpreted from the data that the 11 years old participants had a higher instrumental motivation than the under 11 years old participants. The instrumental motivation deals with the utilitarian purpose of learning the second language. The rise in instrumental motivation may be related to some aspects such as the cognitive and psychological development. This group of participant may have been realized the use of English in their life, so their instrumental motivation in learning English was increased. 
The intrinsic motivation of the older students can be in improved by giving them appropriate materials and activities. The community may also make use of the surrounding environment since the class was held in the students' neighborhood. It can give them a better exposure since the materials and the activity is close with their known environment. In line with that, Lepper and Henderlong (2000) stated that there may be some responses to the decreased intrinsic motivation such as to "promote autonomy and self-determination" and promote children's sense of curiosity by placing learning in meaningful and exciting contexts" (p. 289).

Furthermore, the data unveiled a major difference between the first group and the second group regarding with the anxiety. The data determined that the participants got less anxious in making mistake in the class as they have reached 11 years old. There can be some reasons behind that change. The 11 years old participant may have a better cognitive skill regarding their English. They might also have a better emotion control so that they could cope with their anxiety in making mistake well. The community can use the confidence of the older students to encourage the younger students to cope with their emotional anxiety. It can provide the younger students an example that it is fine to make a mistake in the class.

\section{CONCLUSION AND SUGGESTION}

This study discovered that the children of non-formal EFL program, especially in BaBe Berbagi Community, showed a positive motivation and attitude in terms of four factors, they are interest in foreign countries, intrinsic motivation, caregivers' encouragement, and instrumental motivation. However, the factor analysis also showed that they still felt anxious about the target language.

Based on the age group analysis, the young learners in the non-formal EFL program have different motivation and attitude toward the English. This study exposed that there was a developmental decline of motivation and analysis as the non-formal EFL learners reached 11 years old on almost all underlying factor unless the instrumental motivation, whereas the 11 years old group presented less anxiety than its counterpart. It means that as the EFL learners grow older, they get more confident. It may be due to their English proficiency development. They also feel motivated to study English since they have realized the practical use of English in their live. It happens since the learners have enough cognitive and psychological development to see how their world works.

Dealing with such condition, there are some recommendations for a learning improvement, especially in non-formal EFL educational context. Interest toward foreign language can be increased by showing the learners that languages have common characteristics while at the same they are also unique in nature. The community should create interesting activities to stimulate the children's motivation in the learning process. The parents' encouragement is also important to be done in a long term. As the children grow older, they may have developed an ability to think for themselves, but the parents should also realize that their encouragement is always important. To diminish the anxiety level, a friendly and supporting feedback should be made.

Although this study reveals a new result, some limitations are applied. First, this study only collected quite small number of participant $(n=10)$ in only one area of non-formal EFL educational setting. Second, the age group of participant are consisted of different students. A more accurate result may be obtained if the age group data are collected from the same participants in their before and after 11 years old. Third this study only emphasized on the 
motivational and attitude development based on the age group. A more interesting research may come from the more complex data analysis involving more variables such as the economic factor, gender, and research location.

\section{REFERENCES}

Carreira, J. M. (2006). Motivation for learning English as a foreign language in Japanese elementary schools. JALT Journal, 28, 135-57.

Dörnyei, Z. (2001a). Teaching and researching motivation. Harlow, England: Pearson Education.

Dörnyei, Z. (2001b). New themes and approaches in second language motivation research. Annual Review of Applied Linguistics, 21, 43-59.

Gardner, R. (1985). Social psychology and second language learning: The role of attitudes and motivation. London: Edward Arnold.

Gardner, R. C., \& Lambert, W. E. (1972). Attitudes and motivation in second language learning. Rowley, MA: Newbury House Publishers.

Lepper, M. R., \& Henderlong, J. (2000). Turning "play" into "work" and "work" into "play": 25 years of research on intrinsic versus extrinsic motivation. In C. Sansone \& J. M. Harackiewicz (Eds.), Intrinsic and extrinsic motivation: The search for optimal motivation and performance (pp. 257-372). San Diego, CA: Academic Press.

Nikolov, M. (1999). Why do you learn English? Because the teacher is short: A study of Hungarian children's foreign language learning motivation. Language Teaching Research, 3, 33-56.

Oroujlou, N., Vahedi, M. (2011). Motivation, attitude, and language learning. Procedia - Social and Behavioral Sciences, 29, 994-1000.

Winne, P. H., \& Marx, R. W. (1989). A cognitive-processing analysis of motivation within classroom tasks. In C. Ames \& R. Ames (Eds.), Research on motivation in education. Vol. 3: Goals and cognitions (pp. 223-257). San Diego: Academic Press, Inc. 